\title{
MILLIPEDS PRINCIPALLY COLLECTED BY PROFESSOR V. E. SHELFORD IN THE EASTERN AND SOUTHEASTERN STATES ${ }^{1}$
}

\author{
By H. F. Loomis \\ Coconut Grove, Florida
}

In 1942 and 1943, Professor V. E. Shelford, University of Illinois, Champaign, Illinois, made extensive collections of millipeds in many of the states east of the Mississippi, with some collecting having been done in northeastern Mexico in 1942 . These collections were sent to me for study, the result of which constitutes a large part of this paper. Records of established species have been limited to specimens that could be completely identified; no records of females or immature specimens, of which there were considerable numbers referable only to the genus, have been included as they appeared to be of little faunistic value. Descriptions of several new forms collected by others have been included in the paper but where a collector is not named in connection with any species, new or old, he is understood to have been Professor Shelford.

Type specimens are deposited in the Museum of Comparative Zoology, Cambridge, Massachusetts. Paratype specimens, where available, have been deposited in the U. S. National Museum.

$$
\text { POLYZONIIDAE }
$$

Polyzonium bivirgatum (Wood)

S-1041, Durham, N. C., July 28, 1943; S-2294, Owego, N. Y., Oct. 20, 1943.

\footnotetext{
ANDROGNATHID $A$

Andrognathus corticarius Cope

S-1952, Crittenden, Ky., August 6, 1943.

${ }^{1}$ Published with the aid of a grant from the Museum of Comparative Zoölogy at Harvard College.
} 


\section{CLEIDOGONIDAE}

Pseudotremia sublevis sp. nov.

One male (type) and a dozen other specimens including mature females and juveniles collected in Tony's Cave, Giles Co., Virginia, May 9, 1943 by H. W. Jackson, Virginia Agricultural Experiment Station, Blacksburg, Virginia.

Diagnosis: In the princeps series but with even fewer dorsal tubercles than found in $P$. valga and with less prominent shoulders than other species in the series; gonopods differing from all other species.

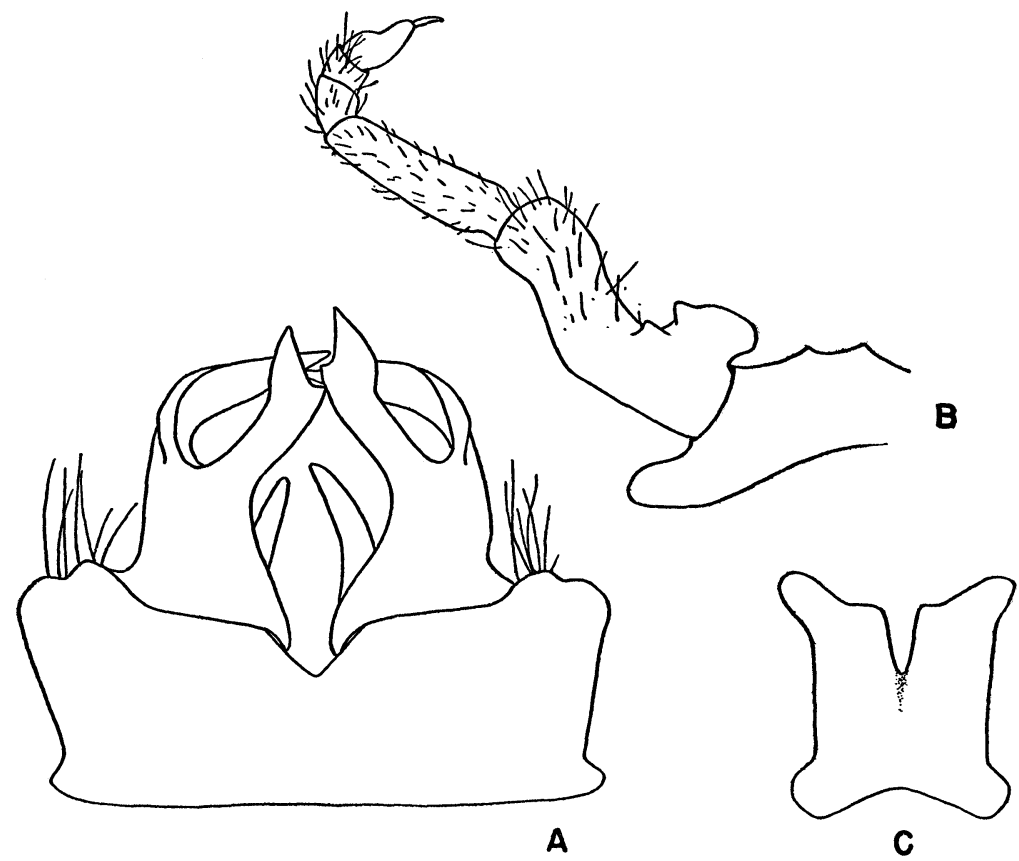

Fig. 1. Pseudotremia sublevis. $a$, Gonopods; $b$, Ninth leg; $c$, Bifid laminae.

Description: Size large, exceeded only by princeps, maximum length $30 \mathrm{~mm}$.; body cylindrical, not rapidly reduced in width at either end, the females even less fusiform than the males with body widest at about segment 9 or 10; color slate bluegray. 
Ocelli 18 or 19, in 6 series paralleling the back margin of the head, 4, 4, 4, 3, 2, 1; counting forward, 5, 4, 4, 3, 2, 1 .

First segment with lateral limits sharply angled, not at all swollen; shoulders of segment 2 small but thereafter increasing in size and thickness to segment 6 or 7 after which their prominence decreases and no definite shoulders are evident after segment 20; none of the shoulders elevated as in princeps or simulans. In the type, tubercles are present adjacent to the shoulders as far forward as segment 7 or 8 ; but in the other specimens the dorsal surface of segments smooth and shining and with no tubercles on the anterior half of the body and with only a few small indistinct ones near the posterior margin adjacent to the shoulders of segments at the third quarter of the body behind which none are present, the tubercles small and most of them appear to be preceded by a tiny longitudinal ridge; dorsal setæ short, stiff and acute.

Gonopods, ninth leg, and bifid lamina of the gonopods shown in figure $1, a, b$ and $c$.

Males with sub-tarsal pads on all legs except the last four pairs.

\section{LYSIOPETALIDAE}

\section{Spirostrephon lactarium (Say)}

M-1782, Gainesville, Fla., July 23, 1942; M-1794, Standing Stone Park, Tenn., July 7, 1942; M-1775 and M-1797, Gatlinburg, Tenn., July 7 and 8, 1942; M-1808, De La Howe, Ga., July 10, 1942; H-72, De La Howe Forest, McCormick, S. C., Dec. 17, 1942; S-518, Haleyville, Ala., July 17, 1943; S-850 and S-858, Pisgah Forest, N. C., July 21, 1943; S-1864, Olive Hill, Ky., Aug. 5, 1943.

\section{Spirostrephon texensis Loomis}

S-434, Urania, La., July 14, 1943.

\section{IULIDAE \\ Ophiulus pilosus (Newport)}

M-1798 and M-1800, Standing Stone State Park, Tenn., July 5, 1942; M-1387, De La Howe, Ga., July 10, 1942.

NEMASOMIDAE

Nemasoma sayanum Bollman.

M-1787, Standing Stone State Park, Tenn., July 5, 1942. 


\section{PARAIULIDAE}

Saiulus canadensis (Newport)

S-1501, Durbin, W. Va., August 1, 1943; S-2209, Rochester, N. Y., October 17, 1943; S-2280, Owego, N. Y., October 20, 1943; S-2356, Ludlow, Pa., October 21, 1943.

Ptyoiulus pennsylvanicus (Brandt)

S-2293, Owego, N. Y., October 20, 1943; S-2356, Ludlow, Pa., October 21, 1943; S-2406 and S-2447, Marienville, Pa., October 21, 1943.

\section{SPIROBOLIDAE}

\section{Arctobolus dolleyi Loomis}

S-349, Urania, La., July 14, 1943; S-515, Haleyville, Ala., July 17, 1943.

\section{Arctobolus marginatus (Say)}

S-805, Barnardsville, N. C., July 20, 1943; S-1269, Monterey, Va., July 30, 1943; S-1641, Mt. Lake, Va., August 3, 1943.

\section{Arctobolus keysi sp. nov.}

The single male, type, collected May 12, 1944 at Lantana, Florida, by Alfred Keys for whom it is my pleasure to name this handsome species.
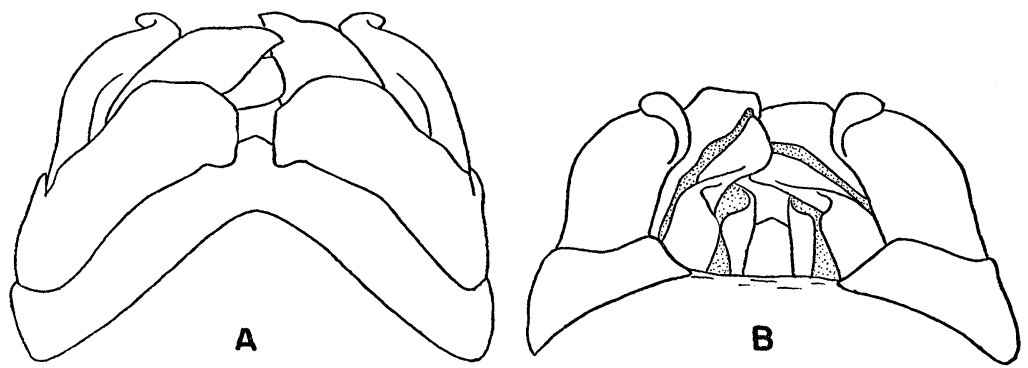

Fig. 2. Arctobolus keysi. a, Gonopods, anterior view; b, Gonopods, posterior view.

Diagnosis: Coloration different from any other known member of the genus and with gonopods structurally distinct.

Description: Length $73 \mathrm{~mm}$; 47 segments. Living color generally light fawn brown or light khaki with the hindfelt of the 
segments slightly darker; narrow anterior margin of the first segment from behind the eyes across its middle bright terracotta, as also are the apex of the last segment and adjacent margin, margins of anal valves and the apex and free margins of the preanal scale; eyes black; antennæ and legs dark horn brown.

Head with ocelli in five series paralleling the antennal socket $-6,8,9,8,7$; clypeus having six setigerous fovea on each side; cardo of mandibles deeply concaved to receive the antennæ, its lower edge high, forming an acute crest, lower anterior corner produced forward into an acute lobe.

Anterior margin of first segment slightly produced forward for a short distance on each side just below the eye; lower limits narrowly rounded. Second segment with downward projection narrow. Surface of body finely and rather sparsely punctate, the punctæ slightly more numerous on the hindbelt.

Gonopods as shown in figure 2, $a$ and $b$.

Seventh segment long at the middle ventrally, not in the least elevated, completely hiding the gonopods within the body.

Coxæ of legs 3, 4, and 5 produced into moderately conspicuous simple conic lobes; coxæ of legs 6 and 7 with smaller lobes.

RHINOCRICIDAE

Rhinocricus potosianus Chamberlin

M-1789, south of Mante, Mex., August 6, 1942.

XYSTODESMIDAE

Aporiaria deturkiana Causey

M-1772 and M-1806, Gatlinburg, Tenn., July 7 and 8, 1943; M-1771 and M-1785, Smoky Mts., Tenn., July 8, 1943.

Zinaria cala Chamberlin

M-1778, San Velasco Hammock, Gainesville, Fla., July 24, 1942.

Cheiropus gen. nov.

Diagnosis: Related to the group of millipeds placed by Chamberlin under Zinaria, but with the outer arm of each gonopod relatively stouter, the inner division of its apex expanded and much larger than the outer division.

Description: Body large, with the dorsum moderately convex and with overlapping lateral carinæ. Gonopods relatively small 
as compared to the size of the body; distal arm of each nearly straight in vertical view, stout, paralleling the opposite arm and terminating in two divisions which together bear some resemblance to a cupped hand with its palm outward and opposed by the thumb.

Type: C. plancus spec. nov.

\section{Cheiropus plancus spec. nov.}

Two males, one the type, from Thomasville, Ga., July 27, 1942 , collected from "climax magnolia-beach" woods, No. M-1810; another male, Gainesville, Florida, July 24, 1942, collected in hammock, No. M-1779.
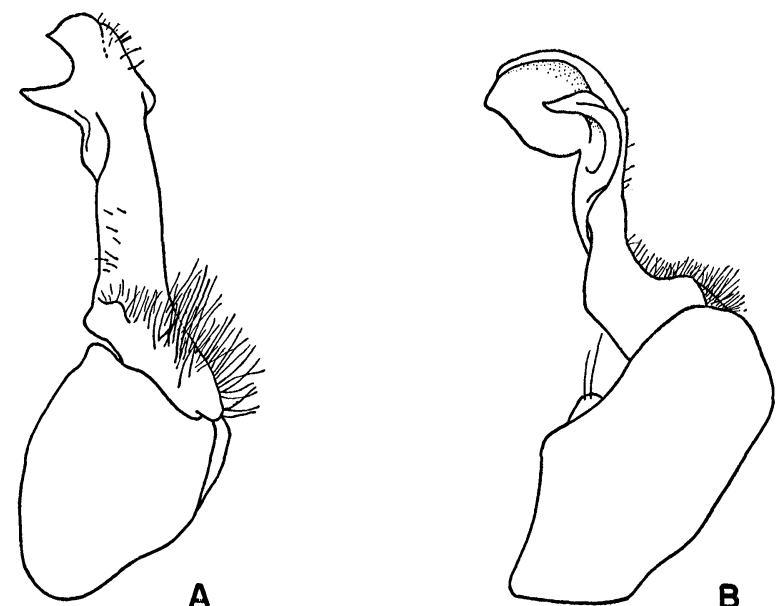

Fig. 3. Cheiropus plancus. a, Left gonopod, posterior view; $b$, Left gonopod, outer lateral view.

Length 38-40 mm., width $10 \mathrm{~mm}$. Surface of dorsum quite coarsely coriaceous. Head and antennæ brown, legs white; segments with dorsum brown except along posterior margin, the back half of the lateral carinæ and their outer portion in front.

Gonopods as shown in figure 3, $a$ and $b$.

Fourth sternum of the male narrow, scarcely exceeded by the fifth which is definitely narrower than those following; none of the anterior sterna with tubercles. In one male the posterior sternum of the segments back of the middle of the body has a 
tiny conic tubercle behind, near the coxal joint of each leg. In the other 2 males there are no sternal tubercles. Following the gonopods the first joint of the legs has a small, slenderly conic tubercle at the ventro-distal limit in 2 males but not in the other; spine at end of second joint of the legs long and slender.

Cleptoria shelfordi sp. nov.

A single male (M-1780) collected in cruising oak-pine woods, De La Howe Forest, Station 11, Georgia, July 10, 1942.

Diagnosis: As with most species in this family, shelfordi differs principally from its relatives in modifications of the gonopods.

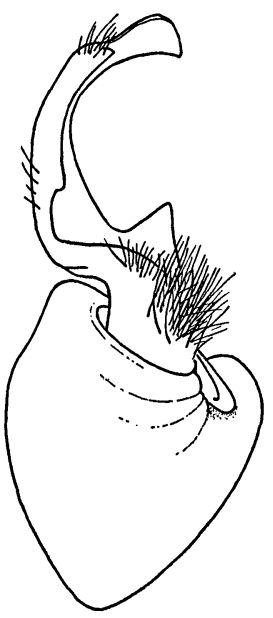

Fig. 4. Cleptoria shelfordi. Left gonopod, posterior view.

Description: Body strongly arched, $58 \mathrm{~mm}$. long and $13 \mathrm{~mm}$. wide; posterior edge of lateral keels slightly overlapping the anterior edge of the ensuing ones; dorsal surface finely coriaceous.

Color of dorsum light brown (in alcohol) to the base of the lateral keels which are colorless; head generally light brown with the antennæ considerably more dilute brown; legs and ventral surfaces colorless.

Gonopods as shown in figure 4.

Sternum between the fourth legs narrow, with two small, high tubercles mesially in contact; fifth sternum wider and 
with a pair of broader, lower, well separated tubercles; sixth sternum with a pair of small tubercles; seventh sternum with fainter elevations bearing a few stiff, erect setæ; sternum immediately behind the gonopods with two small, separated clusters of erect setæ; anterior sterna of segments 9 to 17 usually with a small, faint tubercle on either side behind, adjacent to the leg; posterior sterna with a more prominent tubercle in the same relative position.

Beginning near the middle of the body the first joint of the succeeding legs has a small conic tubercle at the disto-ventral limit; second joint of all legs with the customary spine long and stout.

A remarkable peculiarity of the type is that the eighth segment, which appears normal in other particulars, is without any suggestion of legs.

Mimuloria georgiana (Bollman)

S-516, Haleyville, Ala., July 17, 1943.

Apheloria coriacea (Koch)

S-993, Durham, N. C., July 28, 1943.

Apheloria trimaculata (Wood)

S-1642 and S-1797, Mt. Lake, Va., August 3 and 4, 1943; S-2228, Ithaca, N. Y., October 18, 1943.

Rhysodesmus viabilis Chamberlin

M-1770, north of Mante, Mexico, August 7, 1942.

Stelgipus gen. nov.

Diagnosis: Possibly related to Dynoria but differing in the form of the gonopods which are large, relatively short and heavier than in any other genus of the family.

Description: Size above average; dorsum moderately convex. Gonopods large, the distal joint short, stout, curving toward the body and broadest at the apex. Sterna and first joint of legs, behind the middle of the body at least, with conic tubercles; sterna of mid-body segments with grouped setæ.

Type: S. agrestis sp. nov.

Stelgipus agrestis sp. nov.

The type, a male, was dead and completely bleached when found by the writer in a field of goldenrod at Waynesboro, Ga., June 1943. 
Length $36 \mathrm{~mm}$., width $10 \mathrm{~mm}$. Dorsum somewhat flattened, broadly convex, the surface slightly coriaceous, lateral keels thin with pores on upper surface. First segment with lateral limits extending somewhat further ventrad than in any species of related genera, much exceeding the keels of the ensuing segments.

Gonopods of the form shown in figure 5, $a$ and $b$ with the apical arms crossing each other when at rest.

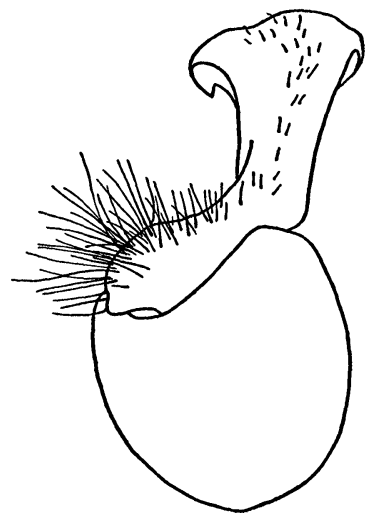

A

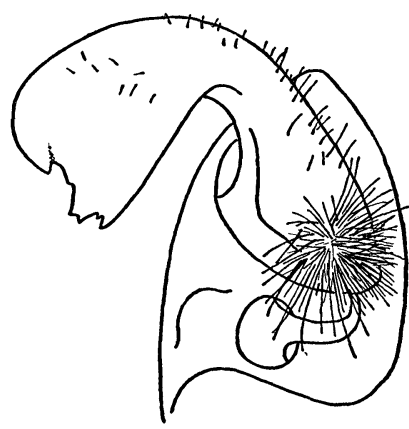

B

Fig. 5. Stelgipus agrestis. $a$, Right gonopod, posterior view; $b$, Right gonopod, mesial view.

Basal joint of legs behind middle of body with a small acute apical tooth below; second joint of all legs with the usual distoventral spine well developed.

Sternum between the third legs narrow and occupied by two small, round, contiguous tubercles; fourth sternum wider, with two small conic tubercles slightly separated and bearing one or two stiff setæ; ensuing sterna wider and without tubercles; all sterna from segment 4 to the middle of the body with a transverse oval area containing a few small setæ; from segment 8 caudad the posterior sterna have a small, broadly conic tubercle near each leg, the anterior sterna with smaller tubercles only on segments behind the middle of the body; sterna behind the gonopods slightly narrower than in related genera. 


\section{EURYURIDAE}

Euryurus falcipes Loomis

S-1949, Crittenden, Ky., August 6, 1943.

POLYDESMIDAE

Polydesmus erasus Loomis

M-1529, M-1777, and M-1793, Standing Stone Park, Tenn., July 5,1942 .

Polydesmus serratus Say

S-1079, Greenlea, Va., July 30, 1943; S-1270, Monterey, Va., July 30, 1943; S-1332 and S-1500, Durbin, W. Va., Aug. 1 and 2, 1943.

\section{Polydesmus moniliaris Koch}

S-1417 and S-1585, Durbin, W. Va., Aug. 1 and 2, 1943; S-1643, Mt. Lake, Va., August 3, 1943.

Lasiolathus virginicus Loomis

S-1941, Crittenden, Ky., Aug. 6, 1943; all young specimens.

STIODESMIDA

Ilyma cajuni sp. nov.

Seven specimens, including three mature males ( 1 the type) collected under bark of orange trees at Venice, La., February 17, 1944 by Morris Gordon, Division of Foreign Plant Quarantines, Bureau of Entomology and Plant Quarantine.

Diagnosis: The great development of the two median rows of tubercles of the penultimate segment into a backwardly produced lobe that far surpasses the tip of the last segment distinguishes this milliped of the Cajun country from its Mexican relatives.

Description: Body white or light yellow but the vertex of head and metazonites with what appears to be a light but general accumulation of dark organic matter adhering to the surface; dorsum high and very strongly arched with lateral keels projecting outward almost horizontally from very low on the sides, their outer extremities at the same level as the coxæ; length of male $7.5 \mathrm{~mm}$., female $8 \mathrm{~mm}$.

Head with vertex abruptly raised on either side of the median line into a narrow tongue-like elevation rounded in front adjacent to the antennal socket with its outer limit behind con- 
tinued as a low granular ridge curving outward far behind the antennal socket and ending in a distinct angulation at the side of the head; front and clypeal area smooth and hispid; labrum broad, the front margin straight across.

First segment with the rather short anterior margin projecting horizontally at almost a right angle to the strongly convex disc, the margin divided into ten rounded scallops separated by acutely angular indentations, the outer scallop on each side

A
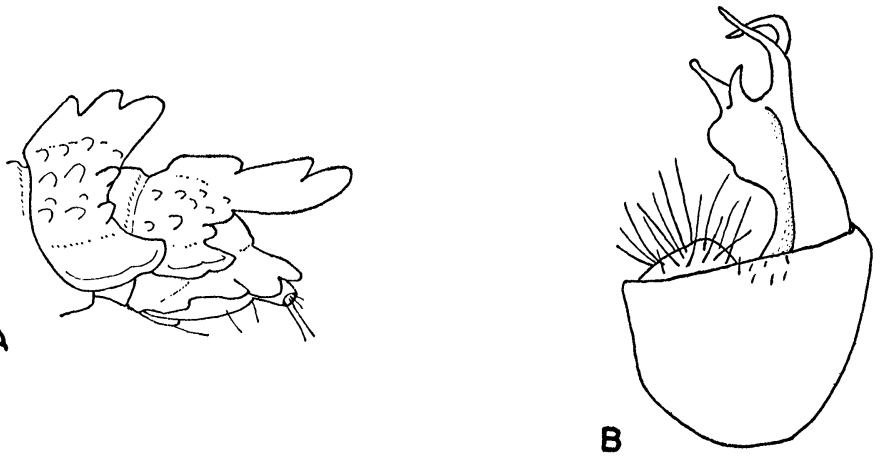

Fig. 6. Ilyma cajuni. a, Segments 18, 19 and 20, lateral view; b, Gonopod.

largest; disc with anterior row of four large tubercles and a posterior row of six similar ones, the surface elsewhere with scattered small granules; posterior margin with about 18 small tubercles projecting backward from it.

Segment 2 with keels projecting at right angles to the long axis of the body, not produced forward; three lobes on the outer margin but only two lobes on the outer margin of the keels on all segments thereafter except the poriferous ones where the posterior lobe is replaced by the large, slenderly conic, truncated pore process.

Segments with four major dorsal longitudinal series of tubercles, three tubercles in each row; the outer row of tubercles on each side less conspicuous than the inner row; small scattered granules present between the large rows of tubercles; keels without tubercles or granules. On segments 17 and 18 the outer rows of large tubercles are reduced in size and are almost lacking from segment 19; on segment 18 the two inner rows of tubercles are enlarged and also are slightly produced beyond the 
posterior margin; on segment 19 these tubercles are flattened and elongated into a process considerably exceeding the tip of segment 20, as shown in figure 6, $a$, and hiding all but the lateral lobes of it from above, the groove between the two produced series of tubercles broad but shallow, the terminal sinus shallow; posterior margin of segment 20 with six distinct lobes or crenations of which the median two are smaller than the two in either side; subapical cone with four long central setæ and with two much shorter setæ laterad of them on either side.

Gonopods somewhat resembling those of $I$. morila Chamberlin as shown in figure $6, b$. 

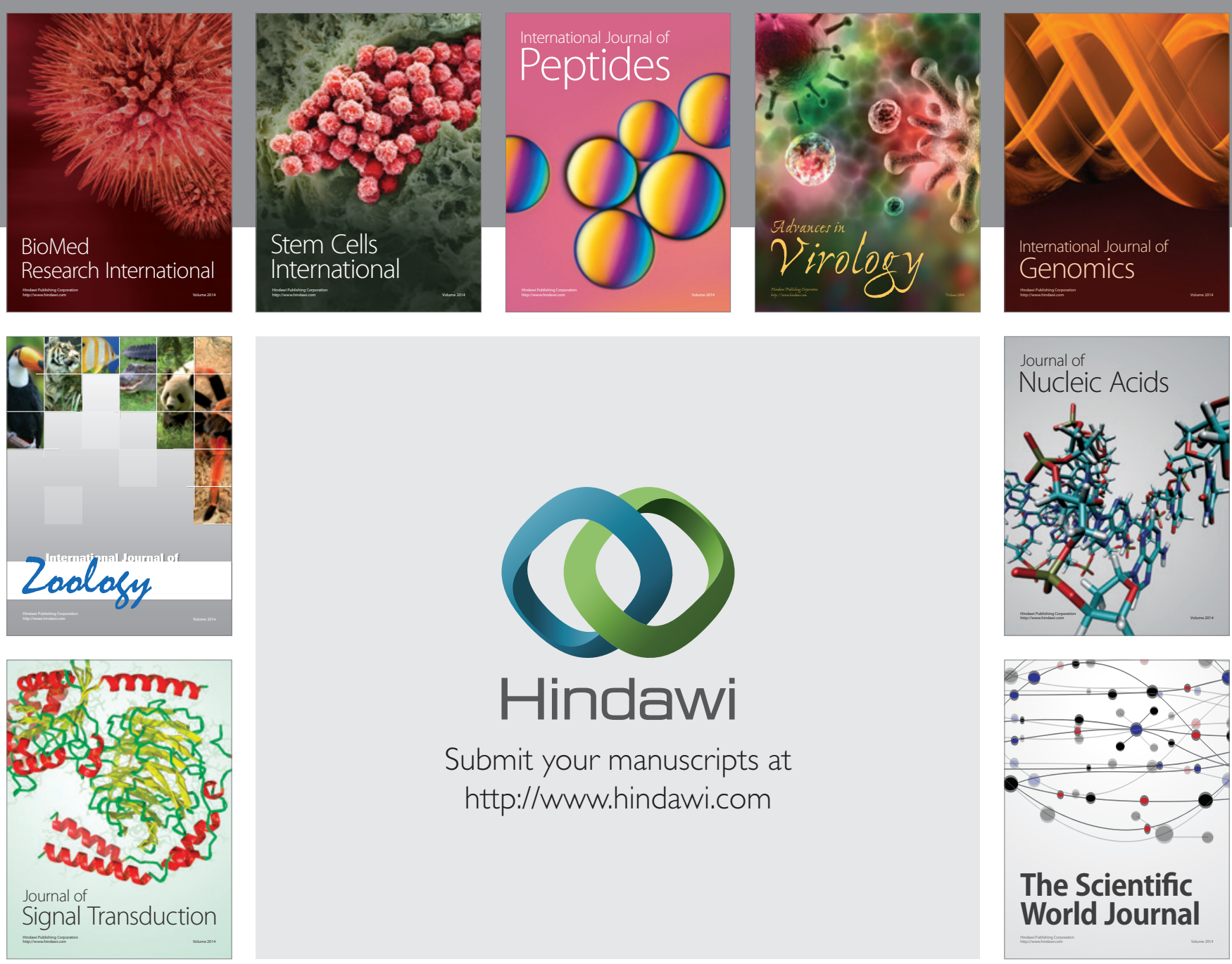

Submit your manuscripts at

http://www.hindawi.com
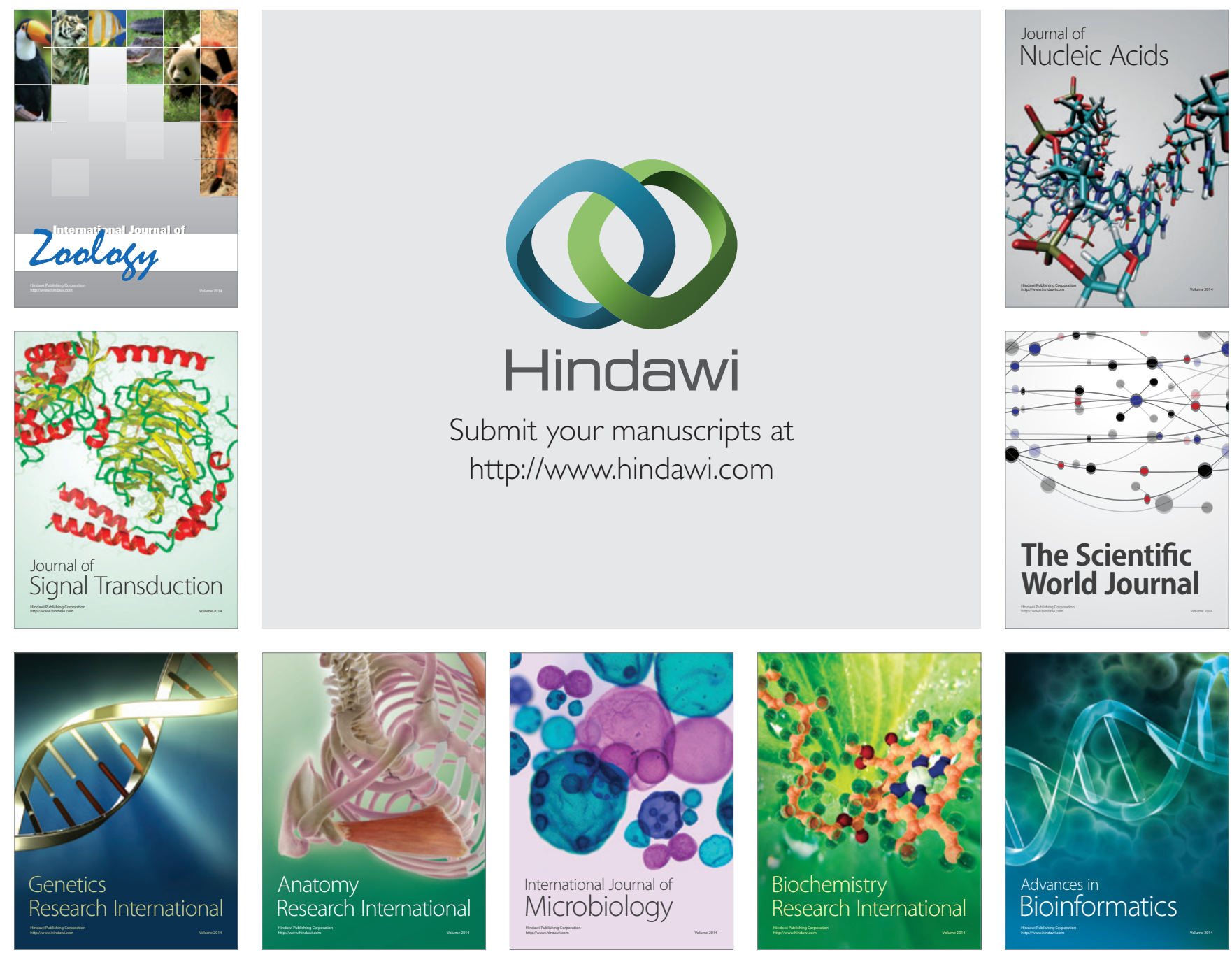

The Scientific World Journal
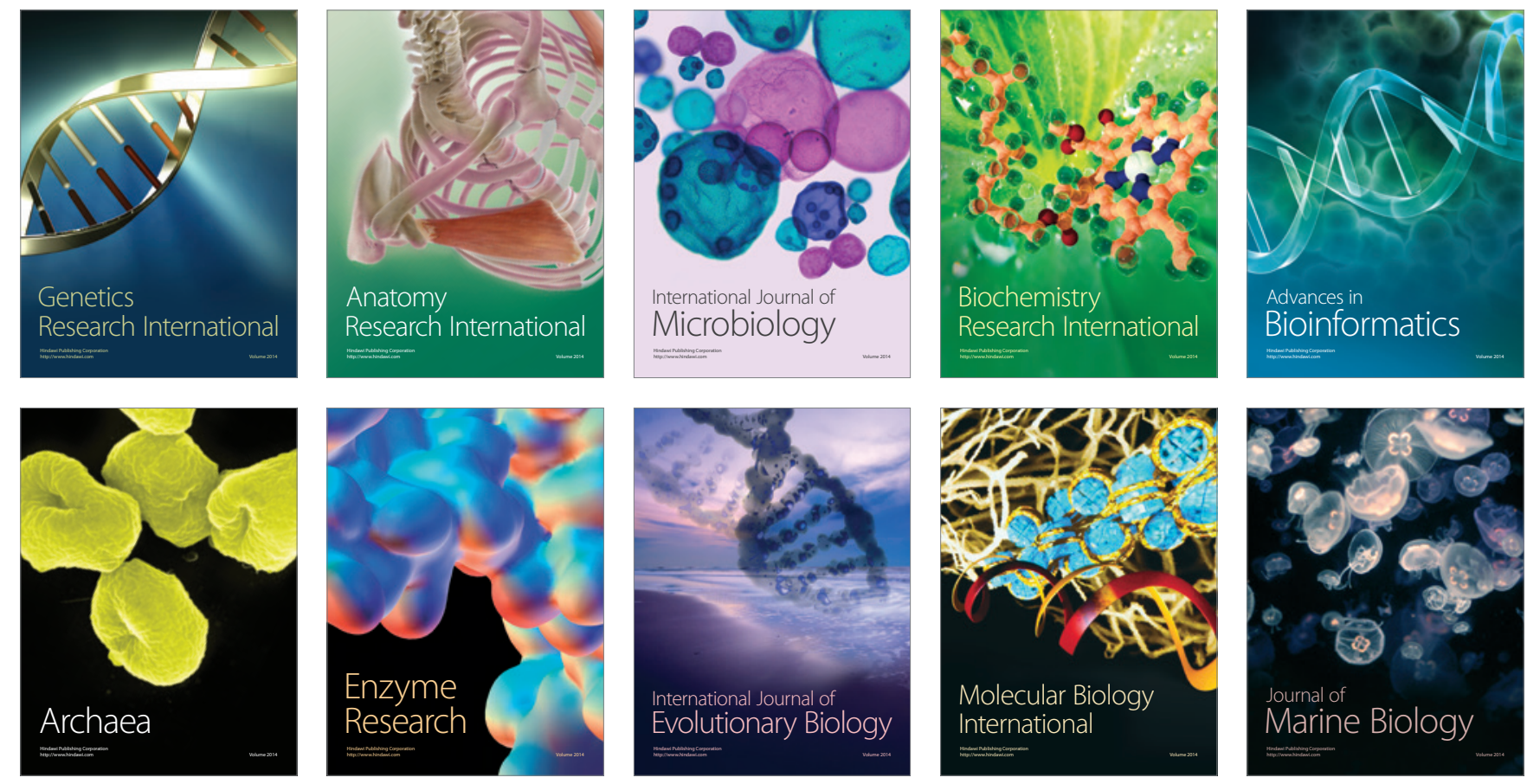